\title{
Bibliotherapy Technique in Improving Learning Motivation
}

\author{
Astrid Lingkan Mandas ${ }^{1}$, Dwi Sarwindah Sukiatni ${ }^{2}$, I Gusti Ayu Agung Noviekayati ${ }^{3}$ \\ \{lingkanmandas@gmail.com \} \\ Faculty of Psychology, University of 17 Agustus 1945 Surabaya ${ }^{1,2,3}$
}

\begin{abstract}
Bibliotherapy is a counseling technique that has a major proportion in which the client needs to identify with one character who has similarities with himself especially when encounter a problem and expected the client can learn from the character how to deal with the problem. In this case, client could identify and learn the motivation contained in the character. This study is concentrated on determining the influence of bibliotherapy in improving learning motivation on high school students and to see the learning motivation before and after application of bibliotherapy. Based on the results, The implementation of bibliotherapy on the subject showed an increasing in learning motivation on subject. Before the implementation of bibliotherapy, subject didn't want to talk about his ideals as an online game programmer and skipping class three times a week. After the implementation, subject wanted to talk about his ideal as an online game programmer. Subject showed capability in making to do list about his future. Subject didn't skip class for about 1 month. For other researchers, during the implementation of bibliotherapy, researchers should also control the other variables such as family so the implementation bibliotherapy could provide a more maximum effect. This study uses single-case experiment method. Sample on this research is a student who has low learning motivation in GIKI Senior High School in Surabaya.
\end{abstract}

Keywords: learning, motivation, bibliotherapy

\section{Introduction}

Success in the educational process is strongly influenced by the learning process as it is the core of the educational process. In the learning process, the motivation that contained within each student is necessarily needed to achieve the learning objectives because motivation is a factor that influence the success in learning process. To be active in the classroom and make the learning atmosphere fun can only happen if there is a motivation.

The success in the learning process can only be achieved if students have motivation in learning [1]. Learning is basically an activity where the brain works at its maximum capacity and of course it can only happen with motivation [2]. Student motivation is influenced by two factors, internal and external factors. Internal factor is the self awareness of the students themselves about how important to learn is to develop themselves and external factors is the stimulation of the surrounding environment.

Outside stimulation can be sourced from family environment, school, and nonsocial environment as natural and instrumental [3]. Outside stimulation can provide inspiration for individuals to perform a work such as learning. Outside stimulation raises the process of identification of the individual against the stimulus. 
Bibliotherapy is a counseling technique where the client learns through a character in a story that has similarity with himself especially the problem he experienced so through the character the client learns how to deal and solve the problem [4].

Bibliotherapy is a technique claimed by several theoretical approaches, however this technique is part of a cognitive-behavioral approach because it has a cognitive element in it. Bibliotherapy is a literacy-based counseling approach where there is an activity of reading a story by a client / counselor before they discuss the content, meaning, and what implications does the story bring for the client. Bibliotherapy is not only limited to reading books but also it does use film or video as material [4].

Through bibliotherapy, individuals are given the opportunity to learn the mindset, behavior, problem solving, and even motivation of the characters in the story or movie / video. In this case, bibliotherapy can help improve student's learning motivation.

Based on the explanation above, the aims of this research is to see the influence of bibliotherapy in improving learning motivation among high school students and see the learning motivation before and after application of bibliotherapy.

The term bibliotherapy comes from Greek, that is biblus which means books, and therapy which means psychological assistance efforts. Therefore, bibliotherapy is therapy that uses books as a tool that can help in solving problems. Bibliotherapy is an expressive therapy where there is a relationship between individual and the contents of book, poems or other kind of writtings packed in the form of therapy [5].

Bibliotherapy or therapeutic storytelling is an expressive therapy that involves storytelling or the reading of specific texts with the purpose of healing. It uses an individual's relationship to the content of books and poetry and other written words as therapy.

Shechtman emphasizes that "bibliotherapy is a fun and pleasingly literature-based therapeutic process that includes activities such as listening to stories or poems, watching movies, and looking at pictures [5].

According to [6] bibliotherapy is a tecnique that creates interaction between facilitator and participant throught literature discussion. Baker gives a clinical definition of Bibliotherapy as a therapy that uses poetry and literature to heal someone with mental and emotional illness [6]. Cohen explains that interactive Bibliotherapy is not just limited to the treatment of clinical problems but also as a therapy for self-development as in education [7]. In an interactive bibliotherapy involves two people, one of them involves professionals such as teachers or facilitators who facilitate student involvement. The purpose of this type of bibliotherapy is to enable participants to achieve success in their education, such as achieving satisfaction and educational attitudes. This therapy also serves to open insights into the various values that can build a person's life [8].

Bibliotherapy aims to change the self-concept of the individual, increasing self-motivation, show the way in finding self-identity, establish self-efficacy, emotional resilience and mental stress, indicating that he is not the only person who has problems, indicating that there is more than one alternative settlement problems, helping someone with problem discussions, helping to plan a step in solving the problem [8].

There are several stages in bibliotherapy : (1) Introduction (motivating activities); (2) reading books or watching videos; (3) incubation ; (4) getting involved in follow-up discussions; 5) evaluation [4]. Bibliotherapy can be an alternative therapy that is easy, cheap, and flexible and can involve full participation with autonomous attitude, so that can be obtained effective results in solving problems that occur in adolescents, especially educational problems such as learning motivation [5]. 
Learning Motivation

Motivation to learn is probably the most important element of learning. Learning certainly cannot be separated from hard work. Hard work itself is about the activity of encouraging the work of the brain to the extent of its ability and only occurs with motivation [2]. Motivation itself means 'the attribute that moves us to do or not to do something' [9]. Motivation is formed from the beliefs, perceptions, values, interests, and actions in which all elements are related to each other [9]. According to Santrock, motivation is a process that gives spirit, direction, and persistence behavior. This means motivated behavior is a behavior that is full of energy, directed, and last long [10].

Motivation has a strategic role in one's learning activities. Wahab describes the function of motivation in learning [3] :

Motivation as A Stimulus

Students may have no desire to learn, but because there is something to look for, there is an interest in learning.

Motivation as A Driving Act

The psychological thrust that generates attitudes toward students is an unstoppable force that manifests in the form of a physiological movement.

Motivation as An Indicator

Motivated students can sorting out which actions to do and which do not. Something that will be sought by students is a learning goal that has to be achieved. The purpose of learning that became indicator for students provides motivation to students in learning.

\section{Method}

This research was conducted in October-November 2016 with the aim to see the effect of bibliotherapy technique in improving learning motivation and to see student's motivation before and after application of bibliotherapy technique. This research used Single-Case Experiment method.

The subject for this research was taken from a high school in Surabaya which have low learning motivation.

In this study, researchers did not use the book as a material but videos of characters who succeeded in their work as an online game programmer and everything related to online game programmer. It suits with the circumstances of the subject who wants to be an online game programmer. The study was conducted through five meetings in five stages.

The first and second session was the motivation stage. At this stage, the first session was an introductory activity such as explaining the problems experienced by the subject, schedule setting, explaining the rules during counseling, and determining the goals that need to be achieved during counseling.

The second session, researcher tried to explore subject's ideals and supplied motivation and support on subject's ideals. On the third session was the second stage where researcher provided videos for subject to watch. At this stage, researcher showed subject video of people who are 
successful with their job as an online game programmers and motivational videos of online game programmers.

The next stage was the incubation period, where researcher gave subject the opportunity to reflect the video he watched. On the fourth session was the fourth stage which was a follow-up activity by discussing the video from the previous meeting. After that on the last stage was the evaluation and closing, reviewing the first until the fifth session.

\section{Result abd Discussion}

The implementation of bibliotherapy on the subject showed an increasing in learning motivation on subject.

Before the implementation of bibliotherapy, Subject didn't want to talk about his ideals as an online game programmer and skipping class three times a week.

After the implementation, subject wanted to talk about his ideal as an online game programmer. Subject talked about the first time he wanted to be an online game programmer. When subject was asked to reflect the parable of school, subject said "School is a field where one must patiently dig to find gold and gold is same as programmer". Subject was able to reflect the video he watched by saying "become a programmer we can do something meaningful". Subject was able to reflect the video by quoting two quotes. First was "you can't do plan B without doing plan A first". Second one was "live your life like a game, make your character as good as you can" Subject showed capability in making to do list for his future. He said "First thing to do is finish school, graduate, and learn how to be a programmer"

On the last stage, subject was able to summarize what he had learnt during counselling and decided to no longer skipping class and sticking out at school until graduate from GIKI Senior High School in Surabaya, pursue his dream to become an online game programmer. Subject didn't skip class for about 1 month.

Before the session began, researcher asked subject to rate his motivation on a scale of ten. Subject said "it's six". At the end of the session researcher ask again and he said "it's eight". [8] on their research found that bibliotherapy can help developing positive mindset on one's mind. Life pattern that contained in the readings, bring forth positivity in one's mind. As for the bibliotherapy given to subject, life pattern from a programmer also gave a cognition to subject about how people with an ideal should live. 


\section{Conclusion}

This study provides techniques to explore subject's ideals about the future and supplied motivation for his ideals. The implementation of bibliotherapy on the subject showed an increasing in learning motivation on subject. Subject wanted to talk about his dream about being an online game programmer, was able to reflect the video, and was able to make a plan about how to become an online game programmer. For other researchers, during the implemantion of bibliotherapy, researchers should also control the other variables such as family so the implementation bibliotherapy can provide a more maximum effect.

Acknowledgements. The authors would like to thank the team and reviewers, especially to Universitas Muhammadiyah Sidoarjo (UMSIDA) that hold the International Conference on Emerging Media, and Social Science December 7-8, 2018 Banyuwangi, Indonesia.

\section{References}

[1] Suprihatin, Siti. Upaya Guru dalam Meningkatkan Motivasi Belajar Siswa. Jurnal Pendidikan Ekonomi Vol 3, No. 1 : 73-82 (2015)

[2] Wieman, Carl. Motivating Learning. CWSEI Seminar. (2013)

[3] Wahab, R. Psikologi Belajar. Jakarta : Rajawali Pers (2016)

[4] Erford, Bradley. T. 40 Teknik yang Harus Diketahui Setiap Konselor Edisi Kedua. Ahli Bahasa oleh Soetjipto, H. P., Soetjipto, S. M. Yogyakarta : Pustaka Pelajar (2016)

[5] Eliasa, E. I. Bibliotherapy As A Method of Meaningful Treatment. Artikel. Universitas Negeri Yogyakarta (2016)

[6] Shechtman, Z. Treating Child and Adolescent Aggression Through Bibliotherapy. America : Springer (2009)

[7] Cohen, L. The Experience of Therapeutic Reading. Western Journal of Nursing Research 16(4): 426-37. (1994)

[8] Trihantoro, A., Hidayat, D. R., Chanum, I. Pengaruh Teknik Biblioterapi Untuk Mengubah Konsep Diri Siswa : Studi Kuasi Eksperimen pada Siswa Kelas VIII SMP Negeri II Tangerang. Jurnal Bimbingan Konseling Vol 5, No. 1: 8-13 (2016)

[9] Lai, E. R. Motivation : A Literatur Review. Pearson Research Report (2011)

[10] Santrock, J.W. Educational Psychology $2^{\text {nd }}$ ed. New York: McGraw-Hill Companies, Inc. (2004) 